\title{
Arsenic, Zinc, and Aluminium Removal from Gold Mine Wastewater Effluents and Accumulation by Submerged Aquatic Plants (Cabomba piauhyensis, Egeria densa, and Hydrilla verticillata)
}

\author{
Ahmad Farid Abu Bakar, ${ }^{1}$ Ismail Yusoff, ${ }^{1} \mathrm{Ng}$ Tham Fatt, ${ }^{1}$ \\ Faridah Othman, ${ }^{2}$ and Muhammad Aqeel Ashraf ${ }^{1}$ \\ ${ }^{1}$ Geology Department, Faculty of Science, University Malaya, 50603 Kuala Lumpur, Malaysia \\ ${ }^{2}$ Civil Engineering Department, Faculty of Engineering, University Malaya, 50603 Kuala Lumpur, Malaysia
}

Correspondence should be addressed to Muhammad Aqeel Ashraf; aqeelashraf@um.edu.my

Received 1 July 2013; Accepted 9 August 2013

Academic Editor: Qaisar Mahmood

Copyright (C) 2013 Ahmad Farid Abu Bakar et al. This is an open access article distributed under the Creative Commons Attribution License, which permits unrestricted use, distribution, and reproduction in any medium, provided the original work is properly cited.

\begin{abstract}
The potential of three submerged aquatic plant species (Cabomba piauhyensis, Egeria densa, and Hydrilla verticillata) to be used for $\mathrm{As}, \mathrm{Al}$, and $\mathrm{Zn}$ phytoremediation was tested. The plants were exposed for 14 days under hydroponic conditions to mine waste water effluents in order to assess the suitability of the aquatic plants to remediate elevated multi-metals concentrations in mine waste water. The results show that the $E$. densa and $H$. verticillata are able to accumulate high amount of arsenic (95.2\%) and zinc (93.7\%) and resulted in a decrease of arsenic and zinc in the ambient water. On the other hand, C. piauhyensis shows remarkable aluminium accumulation in plant biomass (83.8\%) compared to the other tested plants. The ability of these plants to accumulate the studied metals and survive throughout the experiment demonstrates the potential of these plants to remediate metal enriched water especially for mine drainage effluent. Among the three tested aquatic plants, $H$. verticillata was found to be the most applicable $(84.5 \%)$ and suitable plant species to phytoremediate elevated metals and metalloid in mine related waste water.
\end{abstract}

\section{Introduction}

Mining effluent waste water often has elevated concentration of metal and metalloid. This is due to the mine drainage discharge from the metal processing plant and the flushing of weathered material [1] through runoff mechanism [2]. These toxic metals can be transported into the pond, ditch, and river water and may eventually affect the lives of local people that using this water as primary source for their daily requirements [3]. Various remediation strategies may be used to treat the contaminated water, for example, through ion exchange, reverse osmosis, electrolysis, precipitation, and adsorption. However, these methods are usually high cost [4], time consuming, and labor exhaustive and may contribute to the other environmental problem (e.g., dumping site for metal waste).
The plant based remediation technology is an emerging concept aims to accumulate and translocate metal in plant cells and thus removing metal content in water through several phytoremediation processes, namely, phytoextraction, phytodegradation, rhizofiltration, phytostabilization, and phytovolatilization $[5,6]$. This technology uses various types of plants to degrade, extract, contain, or immobilize contaminants in soil [7] and water [8]. In recent years, phytoremediation techniques have received increasing attention due to cost-effective, nonintrusive, and safe alternative compared to conventional cleanup techniques [9].

The aquatic plant can be either floating on the water surface or submerged into the water. The floating aquatic plants accumulate contaminants by its roots [10], while the submerged plants accumulate metals by their whole body. Indirectly, the aquatic plants also may act as traps for 
particulate material, by slowing the water current and favoring sedimentation of suspended particles and thus influencing metal retention in water bodies $[11,12]$. The ability of plants to hyperaccumulate metals and metalloids in plant mass has led to the ideas that sustainable and ecofriendly remediation strategies could be developed based on this characteristic [3]. By definition, a hyperaccumulator must accumulate at least $100 \mathrm{mg} \mathrm{g}^{-1}$ (0.01\% dry wt.), Cd, As, and some other trace metals, $1000 \mathrm{mg} \mathrm{g}^{-1}$ (0.1 dry wt.) Co, Cu, Cr, $\mathrm{Ni}$, and $\mathrm{Pb}$ and $10,000 \mathrm{mg} \mathrm{g}^{-1}(1 \% \mathrm{dw}) \mathrm{Mn}$ and $\mathrm{Ni}$ [13-15].

Several submerged aquatic macrophytes have been investigated for the remediation of natural and wastewater contaminated. For example, the submerged aquatic plant Myriophyllum spicatum L. has been reported as an efficient plant species for the metal-contaminated industrial wastewater treatment [17]. The aquatic plants Rorippa nasturtiumaquaticum (L.) and Mentha spp. accumulate arsenic from contaminated freshwater [18]. Five common aquatic plant species (Typha latifolia, Myriophyllum exalbescens, Potamogeton epihydrus, Sparganium angustifolium, and Sparganium multipedunculatum) were tested for $\mathrm{Al}$ phytoremediation [19]. Kamal et al. (2004) have reported an effective removal of $\mathrm{Fe}, \mathrm{Zn}, \mathrm{Cu}$, and $\mathrm{Hg}$ from contaminated water using Parrot feather (Myriophyllum aquaticum), creeping primrose (Ludwigia palustris), and water mint (Mentha aquatic) [20]. These encouraging results regarding phytoremediation using aquatic plants gained much attention of researchers and scientists to continue exploring in this field.

The objectives of this study were (a) to assess the ability of three submerged aquatic plants (Cabomba piauhyensis Gardner, Egeria densa (Planch), and Hydrilla verticillata (L.F.) (Royle)) to tolerate mine waste water contaminated with multimetals concentrations, (b) to determine the metal accumulation and selectivity for each plant, and (c) to examine the plant ability to remove the toxic metal from water.

\section{Material and Methods}

2.1. Experimental Design and Apparatus. Mine waste water effluent used in this experiment was collected from a pond in gold mining area, located at Kuala Medang area, Lipis, Pahang state, Malaysia, with latitude $4^{\circ} 14^{\prime} 30^{\prime \prime} \mathrm{N}$ to $4^{\circ}$ $17^{\prime \prime} 00^{\prime \prime} \mathrm{N}$ and longitude $101^{\circ} 45^{\prime} 00^{\prime \prime} \mathrm{E}$ to $101^{\circ} 50^{\prime} 00^{\prime \prime} \mathrm{E}$ (Figure 1). The experimental setup consists of holding tanks, lighting systems, and aeration system. Nine plastic vessels were used in this experiment, one box for each plant. Each box $\left(60 \times 120 \times 60 \mathrm{~cm}^{3}\right)$ was filled with $15 \mathrm{~L}$ of mine water. The light intensity $\left(625 \mathrm{hlx} / 7200 \mathrm{~cm}^{2}\right)$ provided by the artificial lighting system was similar to that of natural lighting required for aquatic plants. Each lighting unit consisted of three light $40 \mathrm{~W}$ cool white fluorescent bulbs, $122 \mathrm{~cm}$ in length. The lighting system was placed on the top of each box using wooden supports in such a way that it gave a space of $30 \mathrm{~cm}$ clearance between the light bulbs and the water surface in the box.

The spaces between the light bulbs and the water surface are important in order to achieve a good air circulation, and further provide the heat and light required for plant growth.
The plants were rinsed gently with distilled water to remove debris, and the healthy fronds were placed in plastic vessel. Aquatic macrophytes were cultured at ambient temperature under a daily regime of $12 \mathrm{~h}$ light for the period of 14 days.

2.2. Sampling and Analysis. Water samples were taken using new HDPE bottles with a $20 \mathrm{~mL}$ syringe from different deeps and points of the vessel for a period of 14 days. They were preserved at $\mathrm{pH} 2$, following the methodology described in Section 1060 C of the Standard Methods for the Examination for Water and Wastewater [21]. The metal concentration measurement in water was carried out with Perkin Elmer ICP OES (Inductively Coupled Plasma Optical Emission Spectroscopy). A series of standard solutions (0.01, 0.25, 0.50 , and $1.00 \mathrm{mg} \mathrm{L}^{-1}$ ) were measured as check standards. Each sample was measured (after dilution if necessary) in duplicate.

An approximately $5 \mathrm{~g}$ of aquatic plants was also taken simultaneously during water sampling exercise. The plants were rinsed with distilled water and dried in a convection oven for $24 \mathrm{~h}$ at $40^{\circ} \mathrm{C}$ to avoid any metal loss from plant biomass through evaporation. Plants sample were prepared by microwave digestion with an $\mathrm{HNO}_{3}-\mathrm{H}_{2} \mathrm{O}_{2}$ mixture in closed Teflon vessels (Multiwave 3000, Anton Paar). A $0.3 \mathrm{~g}$ sample was weighted on an analytical balance and placed in the digestion tube; $8.0 \mathrm{~mL} \mathrm{HNO}_{3}(65 \%)$ and $2.0 \mathrm{~mL} \mathrm{H} \mathrm{H}_{2}$ (30\%) were added and placed in a microwave oven. The mixture was then kept at $15 \mathrm{~atm}$ pressure and $160^{\circ} \mathrm{C}$ for $30 \mathrm{~min}$.

The volume was brought to $50.0 \mathrm{~mL}$ with ultrapure water in a calibrated flask. The impurities were removed by filtration [22]. The metal elements were determined by the same analytical methods used for water samples. In each analytical batch, reagent blanks and spiked samples were included in the acid digestion to assess the accuracy of the chemical analysis.

2.3. Metal Removal Efficiency and Bioconcentration Factor. The percentage of metal removal efficiency in water was calculated according to Tanhan et al. 2007 [23]:

$$
\% \text { efficiency }=\frac{C_{0}-C_{1}}{C_{0}} \times 100,
$$

where $C_{0}$ and $C_{1}$ are initial and remaining concentrations of metal in medium $\left(\mathrm{mg} \mathrm{L}^{-1}\right)$.

The bioconcentration factor (BCF) was calculated as follows [24]:

$$
\mathrm{BCF}=\frac{\text { Metal in plant biomass }\left(\mathrm{mg} \mathrm{kg}^{-1}\right)}{\text { Metal in solution }\left(\mathrm{mg} \mathrm{L}^{-1}\right)} \text {. }
$$

2.4. Statistical Analysis. Statistical analyses of experimental data were performed using the SPSS 15.0 package for Windows. Student's $t$-tests were used to detect significant differences of metals concentrations in plant biomass and As, $\mathrm{Al}$, and $\mathrm{Zn}$ concentrations in water samples. Evaluation of significant differences among means was performed using one-way ANOVA followed by Tukey's post-hoc test, with 


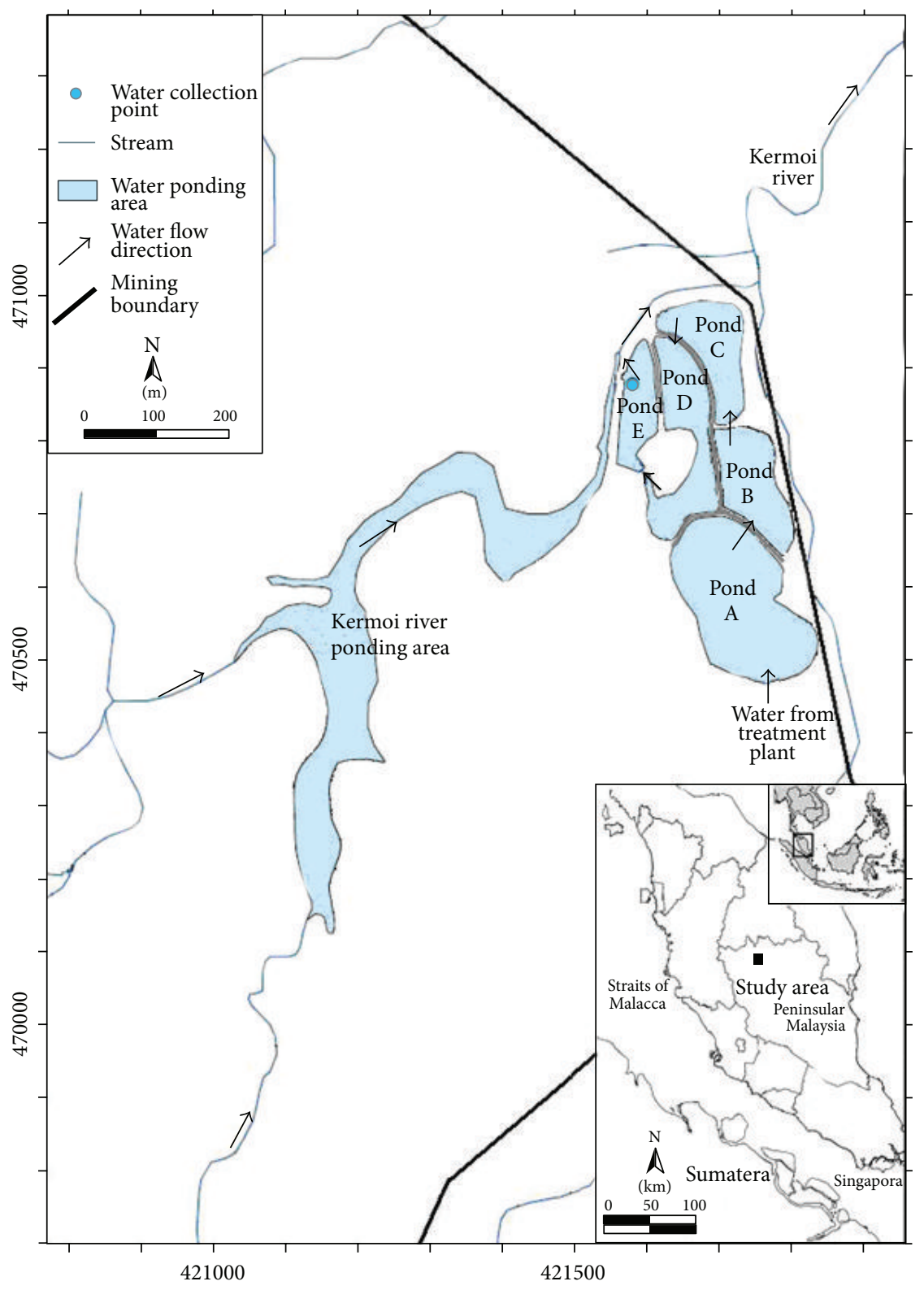

FIGURE 1: The location of the collected mine water effluent used in batch experiments.

$P<0.05$ indicating statistical significance. Spearman product moment correlation coefficients $(r)$ were used to express the associations of quantitative variables.

\section{Result and Discussion}

3.1. Physicochemical Characteristics and Metals Concentrations in Mining Water. The analysis of physicochemical properties of the mining water used in this study showed considerably high levels (Table 1$)$ of total dissolved solids $\left(\mathrm{mg} \mathrm{L}^{-1}\right)$, conductivity (us/cm), and dissolved oxygen $\left(\mathrm{mg} \mathrm{L}^{-1}\right)$. The measured total dissolved solid was $475.3 \mathrm{mg} \mathrm{L}^{-1}, 742.7 \mathrm{us} / \mathrm{cm}$ for conductivity and $7.77 \mathrm{mg} \mathrm{L}^{-1}$ for dissolved oxygen. The measured $\mathrm{pH}$ value during initial experiment was measured at $7.65 \pm 0.18$. As, $\mathrm{Zn}$, and $\mathrm{Al}$ concentrations during initial experiment were measured at $0.21 \pm 0.01 \mathrm{mg} \mathrm{L}^{-1}, 0.11 \pm$ $0.03 \mathrm{mg} \mathrm{L}^{-1}$, and $0.18 \pm 0.04 \mathrm{mg} \mathrm{L}^{-1}$, respectively. The As concentration in water used in this study was higher than drinking water standard by WHO [16].

3.2. Metal Removal Efficiency. The results of the metal removal efficiency using mining effluent for the entire period (14 days) are shown in Figures 2, 3, and 4. After the incubation of macrophytes in the mining effluent, almost all the studied metal concentration in water decreased gradually to a minimum value for all tested plant. The highest removal efficiency (Figure 2) for As was shown by E. densa (95.2\%) followed by $H$. verticillata (84.5\%) and C. piauhyensis (55.8\%). 
TABLE 1: Physicochemical characteristic for mine waste water.

\begin{tabular}{lcc}
\hline Parameters & Value & WHO, 2008 [16] $\left(\mathrm{mg} \mathrm{L}^{-1}\right)$ \\
\hline $\mathrm{pH}$ & $7.65 \pm 0.18$ & \\
$\mathrm{TDS}\left(\mathrm{mg} \mathrm{L}^{-1}\right)$ & $475.3 \pm 1.29$ & \\
Conductivity (us/cm) & $742.7 \pm 5.95$ & \\
$\mathrm{DO}\left(\mathrm{mg} \mathrm{L}^{-1}\right)$ & $7.77 \pm 0.03$ & \\
$\mathrm{~K}\left(\mathrm{mg} \mathrm{L}^{-1}\right)$ & $7.38 \pm 0.24$ & \\
$\mathrm{Ca}\left(\mathrm{mg} \mathrm{L}^{-1}\right)$ & $34.05 \pm 0.69$ & \\
$\mathrm{Mg}\left(\mathrm{mg} \mathrm{L}^{-1}\right)$ & $2.81 \pm 0.08$ & 0.2 \\
$\mathrm{Na}\left(\mathrm{mg} \mathrm{L}^{-1}\right)$ & $21.43 \pm 1.26$ & 3 \\
$\mathrm{Al}\left(\mathrm{mg} \mathrm{L}^{-1}\right)$ & $0.21 \pm 0.04$ & 0.01 \\
$\mathrm{Zn}\left(\mathrm{mg} \mathrm{L}^{-1}\right)$ & $0.11 \pm 0.03$ & \\
$\mathrm{As}\left(\mathrm{mg} \mathrm{L}^{-1}\right)$ & $0.21 \pm 0.01$ & \\
\hline
\end{tabular}

The considerably high As removal efficiencies by $H$. verticillata in this study can be compared with those reported by Srivastava et al. who reports significant As accumulation in plants biomass with removal of more than $70 \%$ of total As supplied after 45 days of treatments [25]. They also proposed $H$. verticillata as a promising aquatic plant for the phytoremediation of arsenic-contaminated water. Lee et al. suggest that high As concentration in H. verticillata is due to As uptake mechanism [26].

The $E$. densa also shows the highest removal efficiency for $\mathrm{Zn}(93.7 \%)$ followed by $H$. verticillata (92.3\%) and C. piauhyensis (87.4\%) (Figure 3). The highest removal efficiency for $\mathrm{Zn}$ by $E$. densa was also been reported by Módenes et al. [27]. Their study demonstrated that $E$. densa is able to remove more than $70 \%$ of $\mathrm{Zn}$ ions from solution, thus indicating the removal potential of $\mathrm{Zn}$ by $E$. densa. The effectiveness of $H$. verticillata in removing $\mathrm{Zn}$ from water has been observed by Dixit and Dhote, who studied $\mathrm{Zn}$ uptake and morphological changes of $H$. verticillata on a dose response basis [28]. They found that the $\mathrm{Zn}$ concentration in water was decreased by 60-80\% after 4 weeks. The highest removal efficiency for $\mathrm{Al}$ (Figure 4) was demonstrated by C. piauhyensis (83.8\%), followed by $H$. verticillata (59.1\%) and E. densa (30.3\%), respectively.

These results show that the metal removal efficiency was varied for different aquatic plant, and E. densa and $H$. verticillata show a potential for $A s$ and $\mathrm{Zn}$ remediation, while $C$. piauhyensis demonstrates the highest $\mathrm{Al}$ removal effectiveness from mining waste water. Since water used in this experiment was also contaminated with many other metals and ions, the results demonstrate that the plants could maintain their potential for $\mathrm{As}, \mathrm{Al}$, and $\mathrm{Zn}$ accumulations even in the presence of other metals and ions, which is in conformity with observation by Srivastava et al. [29].

3.3. Metals Accumulation in Plants Biomass and BCF. Almost all aquatic plants used in the experiment show significant accumulation of studied metal ( $\mathrm{Al}, \mathrm{As}$, and $\mathrm{Zn})$ during entire experimental period (Figure 5). After 14 days of mine waste water exposure, E. densa shows the highest As accumulation $\left(195.95 \mathrm{mg} \mathrm{kg}^{-1} \mathrm{dw}\right.$ ) compared to $H$. verticillata $\left(168.75 \mathrm{mg} \mathrm{kg}^{-1} \mathrm{dw}\right)$ and C. piauhyensis $\left(66.86 \mathrm{mg} \mathrm{kg}^{-1} \mathrm{dw}\right)$.

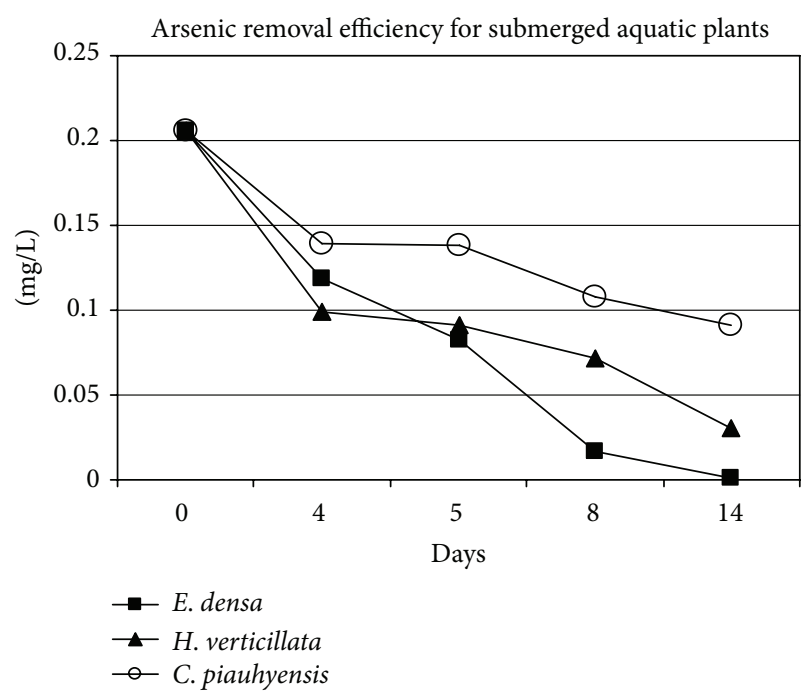

FIgURE 2: Arsenic removal trend for C. piauhyensis, E. densa, and $H$. verticillata.

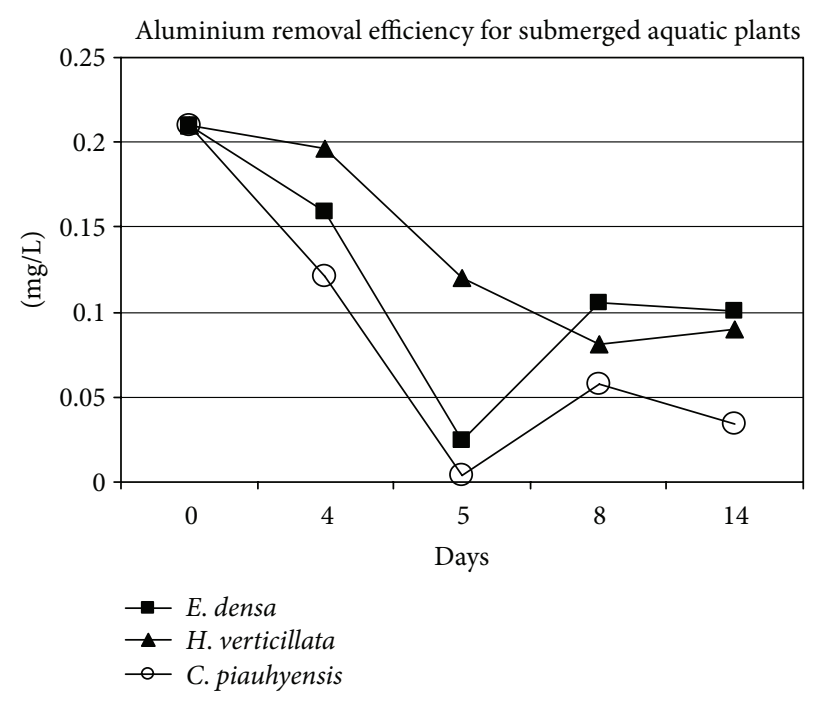

Figure 3: Aluminium removal trend for C. piauhyensis, E. densa, and $H$. verticillata.

The As accumulation in E. densa, however, was considerably low compared to the results of Robinson et al. who observed more than $1000 \mathrm{mg} \mathrm{kg}^{-1}$ of As accumulation in samples of $E$. densa (dry weight) collected in the Waikato river system [18]. This may be due to the extralong exposure time of E. densa to Waikato river water and sample, was collected from their own natural habitat. The As accumulation by $H$. verticillata in this study also can be compared to the study by Srivastava et al. who reported a slightly higher value $\left(195 \mathrm{mg} \mathrm{kg}^{-1}\right)$ than our findings of As accumulation in plant biomass after 15 days of exposure to As concentrated solution [29].

The highest $\mathrm{Zn}$ accumulated was demonstrated by $H$. verticillata $\left(509.05 \mathrm{mg} \mathrm{kg}^{-1} \mathrm{dw}\right.$ ), followed by $E$. densa (441.38 $\mathrm{mg} \mathrm{kg}^{-1} \mathrm{dw}$ ) and C. piauhyensis (280.82 $\mathrm{mg} \mathrm{kg}^{-1} \mathrm{dw}$ ). This result can be compared to the study by Srivastava et al. 


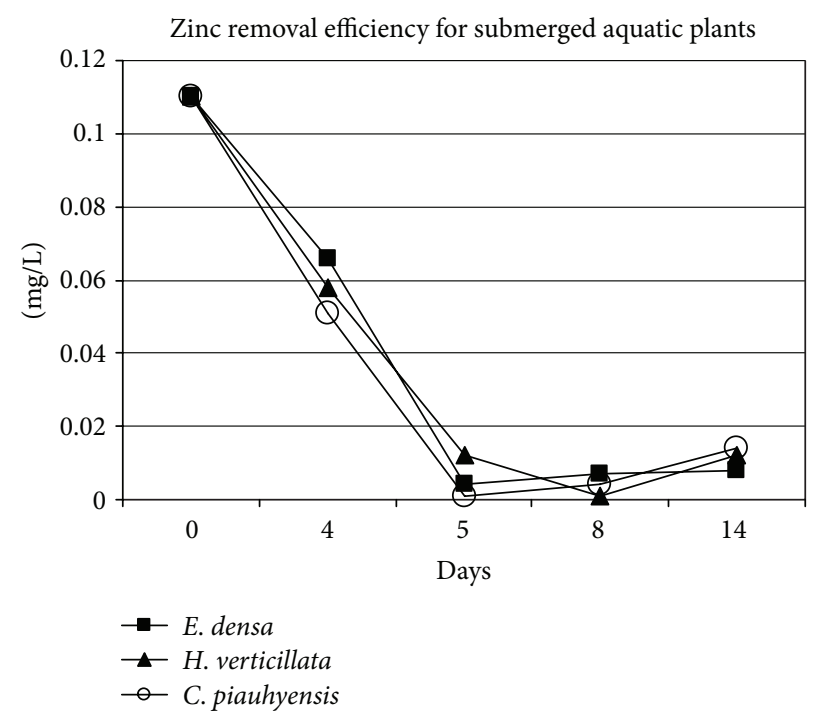

Figure 4: Zinc removal trend for C. piauhyensis, E. densa, and $H$. verticillata.

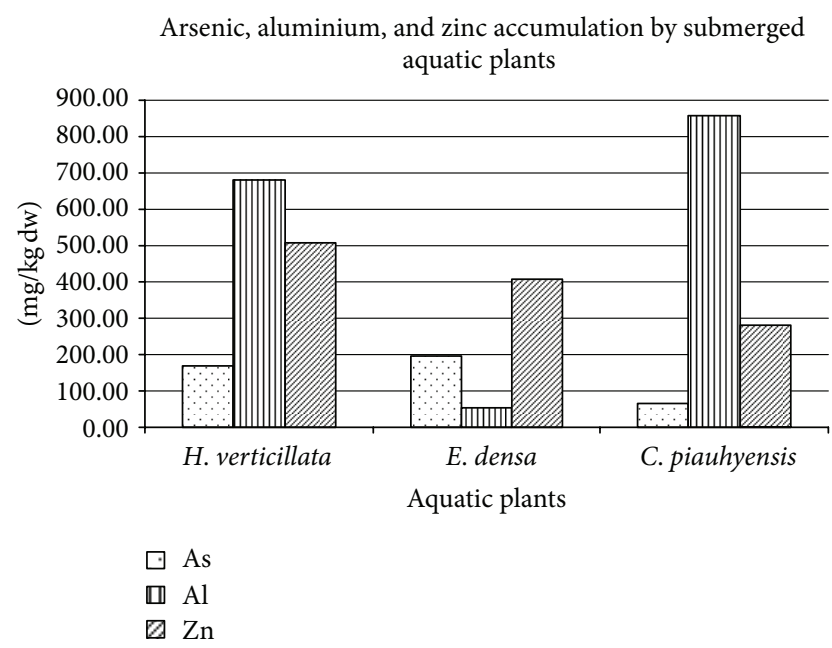

Figure 5: Metal accumulation $(\mathrm{mg} / \mathrm{kg} \mathrm{dw})$ by $C$. piauhyensis, E. densa, and $H$. verticillata.

who demonstrated the ability of $H$. verticillata plants to accumulate significant amounts of $\mathrm{Zn}$ further until hyperaccumulation limit, without showing any visible symptoms of toxicity [29]. The C. piauhyensis has the highest $\mathrm{Al}$ accumulation $\left(856.82 \mathrm{mg} \mathrm{kg}^{-1} \mathrm{dw}\right.$ ) compared to $H$. verticillata (280.82 $\mathrm{mg} \mathrm{kg}^{-1} \mathrm{dw}$ ) and E. densa $\left(66.86 \mathrm{mg} \mathrm{kg}^{-1} \mathrm{dw}\right.$ ).

The bioconcentration factor (BCF) was used to quantify metal accumulation in plant biomass (Figure 6). The use of $\mathrm{BCF}$ is more significant compared to the metal amount accumulated in plants since it provides an index of the ability of the plants to accumulate metal element with respect to the element concentration in water [30]. At the end of experiment (14 days), the $E$. densa shows the highest As BCF value $(1.96 E+05)$ compared to $H$. verticillata $(5.63 E+03)$ and C. piauhyensis $(7.35 E+02)$. The highest $\mathrm{Zn} \mathrm{BCF}$ value was demonstrated by $H$. verticillata followed by E. densa
Submerged aquatic plants bioaccumulation factor

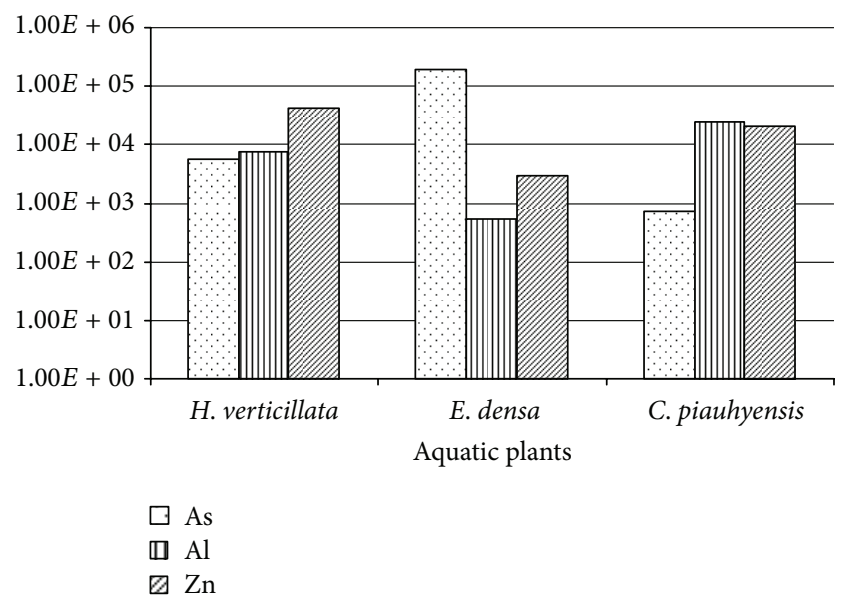

Figure 6: The bioaccumulation factor for C. piauhyensis, E. densa, and $H$. verticillata at the end of experiment (day 14th).

and C. piauhyensis with calculated BCF value that was $4.24 E+$ $04,2.01 E+04$, and $2.94 E+03$, respectively. C. piauhyensis has the highest $\mathrm{BCF}$ for $\mathrm{Al}(2.52 E+04)$ compared to $E$. densa $(7.55 E+03)$ and $H$. verticillata $(5.40 E+02)$. The considerably high BCFs values for $E$. densa for As, $H$. verticillata for $\mathrm{Zn}$, and $C$. piauhyensis for $\mathrm{Al}$, reflected the ability of this plant species to accumulate these metals from mining waste water and to transport them from the roots to shoots.

3.4. Relationships between $A s, A l$, and $Z n$ Accumulated by Aquatic Plants and Metals Removal from Mine Water. Spearman's correlations were used to analyze the relationship between the studied metal (As, $\mathrm{Al}$, and $\mathrm{Zn}$ ) accumulations by aquatic plants and metal concentration in mine water throughout experimental period. A strong significant correlation $(-0.90, P<0.05)$ was observed for As $H$. verticillata and $C$. piauhyensis $(-0.92, P<0.05)$. Although nonsignificant correlation was observed for As in E. densa (-0.70), the plant shows a significantly strong relationship $(-0.90$, $P<0.05)$ for $\mathrm{Zn}$. H. verticulata shows a strong correlation $(-0.82$, nonsignificant) while a relatively low correlation was observed for $\mathrm{Zn}$ in C. piauhyensis (-0.40, nonsignificant).

All aquatic plants show a nonsignificant low correlation for $\mathrm{Al}$ accumulated in plant and $\mathrm{Al}$ in water. A negative correlation between metal accumulated in plant and within mine water clearly demonstrated the ability of these plant in removing metal concentration in solution through adsorbing and accumulation the metal in plant mass, thus, reflecting the potential used of these plants for metal phytoremediation purposes.

3.5. Plant Tolerance and Potential Plant Species for Mine Drainage Remediation. Generally, all the experimental plants did not show any reduction in the plant growth and any physical deterioration. There was no reverse effect, such as chlorosis, necrosis, and whitish-brown color, observed in the plant mass. By the end of the experiment, all the plants 
were survived. This shows that these plants are suitable and survived in water that contains multiconcentrations of metal, mostly found in mine drainage water. The plant survival in water with relatively high metal content is a major characteristic in selecting suitable candidate for metal phytoremediation plant that will be grown in mine drainage effluent.

These submerged plants are also favourable to stabilize mine drainage effluent because these plants are able take up more metals, using their whole biomass as the metals uptake mechanisms can occur through entire plant surface [31]. Submerged species of aquatic macrophytes generally contained higher trace element levels than did floating-leafed species [32].

Plants with invasive behaviour such as $H$. verticillata and E. densa have a wide ecological range. These plants possess a more promising result as a candidate for potential phytoremediation. This is due to their nature that easy to grown and only need minimal treatment. At a nutrient rich situation, these plants, however, cannot been planted together because of $H$. verticillata is a better competitor than $E$. densa and will out-compete successfully $E$. densa [33]. These plants were also suitable for remediation of water with elevated As concentration as proposed by Srivastava et al. [25] using $H$. verticillata and E. densa by Robinson et al. [18].

\section{Conclusion}

Results of this study indicate that $E$. densa and $H$. verticillata have relatively high As and $\mathrm{Zn}$ accumulation in plant mass and are able to remove these metal from mine water effluent. On the other hand, C. piauhyensis demonstrates the highest $\mathrm{Al}$ removed from mine water and accumulated in plant mass. The present study also provides an insight into the mechanisms of As, $\mathrm{Zn}$, and $\mathrm{Al}$ accumulation and resistance in $E$. densa, $H$. verticillata, and $C$. piauhyensis, respectively. The ability of these plants to accumulate the studied metals and survive throughout the experiment demonstrates the potential of these plant to remediate metal enriched water especially for mine drainage effluent treatments.

\section{Conflict of Interests}

The authors indicate no conflict of interests.

\section{Acknowledgments}

The work reported in this paper was carried out through Institute of Research Management and Monitoring, University of Malaya (IPPP-UM), Research Grant nos. PS366/2010A and BK006-2013. The authors are grateful to Miss Nurhayati and Mr. Yusri for laboratory assistance and Mr. Rosli, $\mathrm{Mr}$ Samsudin, Miss Ng Hwei Chih, and mine operator personnel for fieldwork. The authors also thank the two anonymous reviewers for their comments and suggestions.

\section{References}

[1] S. Wei, J. A. Teixeira da Silva, and Q. Zhou, "Agro-improving method of phytoextracting heavy metal contaminated soil," Journal of Hazardous Materials, vol. 150, no. 3, pp. 662-668, 2008.

[2] M. H. Bibi, F. Ahmed, and H. Ishiga, "Assessment of metal concentrations in lake sediments of southwest Japan based on sediment quality guidelines," Environmental Geology, vol. 52, no. 4, pp. 625-639, 2007.

[3] U. N. Rai, S. Sinha, R. D. Tripathi, and P. Chandra, "Wastewater treatability potential of some aquatic macrophytes: removal of heavy metals," Ecological Engineering, vol. 5, no. 1, pp. 5-12, 1995.

[4] L. T. Danh, P. Truong, R. Mammucari, T. Tran, and N. Foster, "Vetiver grass, Vetiveria zizanioides: a choice plant for phytoremediation of heavy metals and organic wastes," International Journal of Phytoremediation, vol. 11, no. 8, pp. 664-691, 2009.

[5] X. Long, X. Yang, and W. Ni, "Current situation and prospect on the remediation of soils contaminated by heavy metals," Journal of Applied Ecology, vol. 13, no. 6, pp. 757-762, 2002.

[6] C. D. Jadia and M. H. Fulekar, "Phytoremediation of heavy metals: recent techniques," African Journal of Biotechnology, vol. 8, no. 6, pp. 921-928, 2009.

[7] M. A. Ashraf, M. J. Maah, and I. Yusoff, "Heavy metals accumulation in plants growing on former tin mining catchment," International Journal of Environmental Science and Technology, vol. 8, no. 2, pp. 401-416, 2011.

[8] J. Zavoda, T. Cutright, J. Szpak, and E. Fallon, "Uptake, selectivity, and inhibition of Hydroponic treatment of contaminants," Journal of Environmental Engineering, vol. 127, no. 6, pp. 502508, 2001.

[9] B. R. Glick, "Phytoremediation: synergistic use of plants and bacteria to clean up the environment," Biotechnology Advances, vol. 21, no. 5, pp. 383-393, 2003.

[10] X. Zhang, Y. Hu, Y. Liu, and B. Chen, "Arsenic uptake, accumulation and phytofiltration by duckweed (Spirodela polyrhiza L.)," Journal of Environmental Sciences, vol. 23, no. 4, pp. 601606, 2011.

[11] Y. Hosokawa and T. Horie, "Flow and particulate nutrient removal by wetland with emergent macrophyte," Science of the Total Environment, vol. 1, pp. 1271-1282, 1992.

[12] R. H. Kadlec, R. L. Knight, J. Vymazal, H. Brix, P. Cooper, and R. Habert, Constructed Wetlands For Pollution Control: Processes, Performance, Design and Operation, International Water Association, London, UK, 2000.

[13] S. Bunluesin, M. Kruatrachue, P. Pokethitiyook, G. R. Lanza, E. S. Upatham, and V. Soonthornsarathool, "Plant screening and comparison of Ceratophyllum demersum and Hydrilla verticillata for cadmium accumulation," Bulletin of Environmental Contamination and Toxicology, vol. 73, no. 3, pp. 591-598, 2004.

[14] R. D. Reeves and A. J. M. Baker, "Metal accumulating plants," in Phytoremediation of Toxic Metals: Using Plants to Clean Up the Environment, I. Raskin and B. D. Ensley, Eds., pp. 193-230, John Wiley \& Sons, New York, NY,USA, 2000.

[15] M. E. Watanabe, "Phytoremediation on the brink of commercialization," Environmental Science and Technology, vol. 31, no. 4, pp. 182A-186A, 1997.

[16] WHO, Guidelines For Drinking-Water Quality, Geneva, Switzerland, 3rd edition, 2008.

[17] E. Lesage, C. Mundia, D. P. L. Rousseau et al., "Sorption of $\mathrm{Co}, \mathrm{Cu}, \mathrm{Ni}$ and $\mathrm{Zn}$ from industrial effluents by the submerged 
aquatic macrophyte Myriophyllum spicatum L," Ecological Engineering, vol. 30, no. 4, pp. 320-325, 2007.

[18] B. Robinson, N. Kim, M. Marchetti et al., "Arsenic hyperaccumulation by aquatic macrophytes in the Taupo Volcanic Zone, New Zealand," Environmental and Experimental Botany, vol. 58, no. 1-3, pp. 206-215, 2006.

[19] C. Gallon, C. Munger, S. Prémont, and P. G. Campbell, "Hydroponic study of aluminum accumulation by aquatic plants: effects of fluoride and $\mathrm{pH}$," Water, Air, and Soil Pollution, vol. 153, no. 1-4, pp. 135-155, 2004.

[20] M. Kamal, A. E. Ghaly, N. Mahmoud, and R. Côté, "Phytoaccumulation of heavy metals by aquatic plants," Environment International, vol. 29, no. 8, pp. 1029-1039, 2004.

[21] A. Eaton, Methods For Water and Wastewater Examination, United Book Press, Baltimore, Md, USA, 19th edition, 1995.

[22] B. A. Zarcinas, C. F. Ishak, M. J. McLaughlin, and G. Cozens, "Heavy metals in soils and crops in southeast Asia. 1. peninsular Malaysia," Environmental Geochemistry and Health, vol. 26, no. 4, pp. 343-357, 2004.

[23] P. Tanhan, M. Kruatrachue, P. Pokethitiyook, and R. Chaiyarat, "Uptake and accumulation of cadmium, lead and zinc by Siam weed [Chromolaena odorata (L.) King \& Robinson]," Chemosphere, vol. 68, no. 2, pp. 323-329, 2007.

[24] G. N. H. Rahmani and S. P. K. Sternberg, "Bioremoval of lead from water using Lemna minor," Bioresource Technology, vol. 70, no. 3, pp. 225-230, 1999.

[25] S. Srivastava and S. F. D’Souza, "Increasing sulfur supply enhances tolerance to arsenic and its accumulation in Hydrilla verticillata (L.f.) Royle," Environmental Science and Technology, vol. 43, no. 16, pp. 6308-6313, 2009.

[26] C. K. Lee, K. S. Low, and N. S. Hew, "Accumulation of arsenic by aquatic plants," Science of the Total Environment, vol. 103, no. 2-3, pp. 215-227, 1991.

[27] A. N. Módenes, J. M. T. D. A. Pietrobelli, F. R. E. Quiñones, P. Y. R. Suzaki, V. L. Alflen, and M. R. D. S. F. Klen, "Biosorption potential of zinc by egeria densa macrophytes," Engenharia Sanitaria e Ambiental, vol. 14, no. 4, pp. 465-470, 2009.

[28] S. Dixit and S. Dhote, "Evaluation of uptake rate of heavy metals by Eichhornia crassipes and Hydrilla verticillata," Environmental Monitoring and Assessment, vol. 169, no. 1-4, pp. 367-374, 2010.

[29] S. Srivastava, S. Mishra, R. D. Tripathi, S. Dwivedi, P. K. Trivedi, and P. K. Tandon, "Phytochelatins and antioxidant systems respond differentially during arsenite and arsenate stress in Hydrilla verticillata (L.f.) Royle," Environmental Science and Technology, vol. 41, no. 8, pp. 2930-2936, 2007.

[30] N. Khellaf and M. Zerdaoui, "Phytoaccumulation of zinc by the aquatic plant, Lemna gibba L," Bioresource Technology, vol. 100, no. 23, pp. 6137-6140, 2009.

[31] J. Nyquist and M. Greger, "A field study of constructed wetlands for preventing and treating acid mine drainage," Ecological Engineering, vol. 35, no. 5, pp. 630-642, 2009.

[32] M. Sprenger and A. McIntosh, "Relationship between concentrations of aluminum, cadmium, lead, and zinc in water, sediments, and aquatic macrophytes in six acidic lakes," Archives of Environmental Contamination and Toxicology, vol. 18, no. 1-2, pp. 225-231, 1989.

[33] C. Mony, T. J. Koschnick, W. T. Haller, and S. Muller, "Competition between two invasive Hydrocharitaceae (Hydrilla verticillata (L.f.) (Royle) and Egeria densa (Planch)) as influenced by sediment fertility and season," Aquatic Botany, vol. 86, no. 3, pp. 236-242, 2007. 

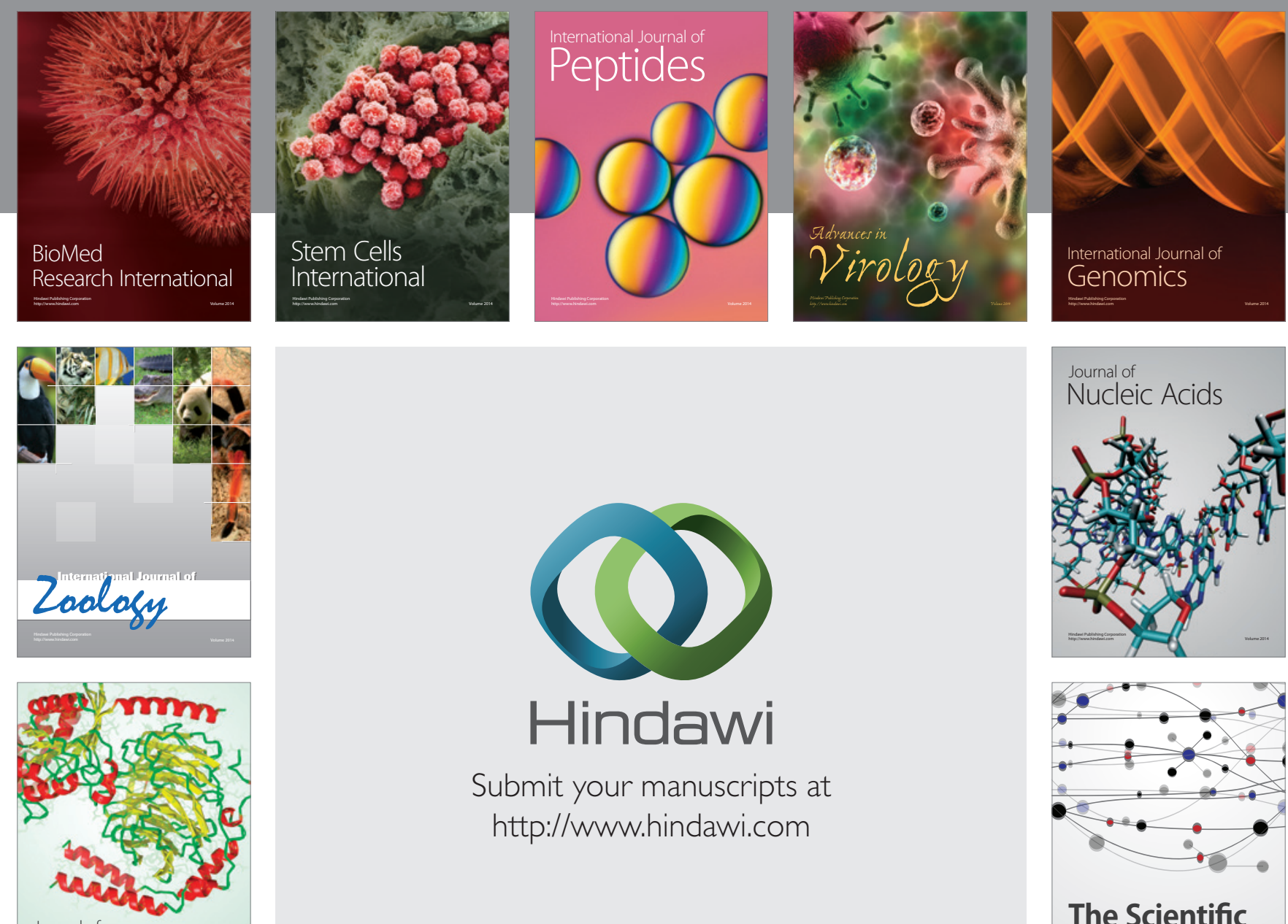

Submit your manuscripts at

http://www.hindawi.com

Journal of
Signal Transduction
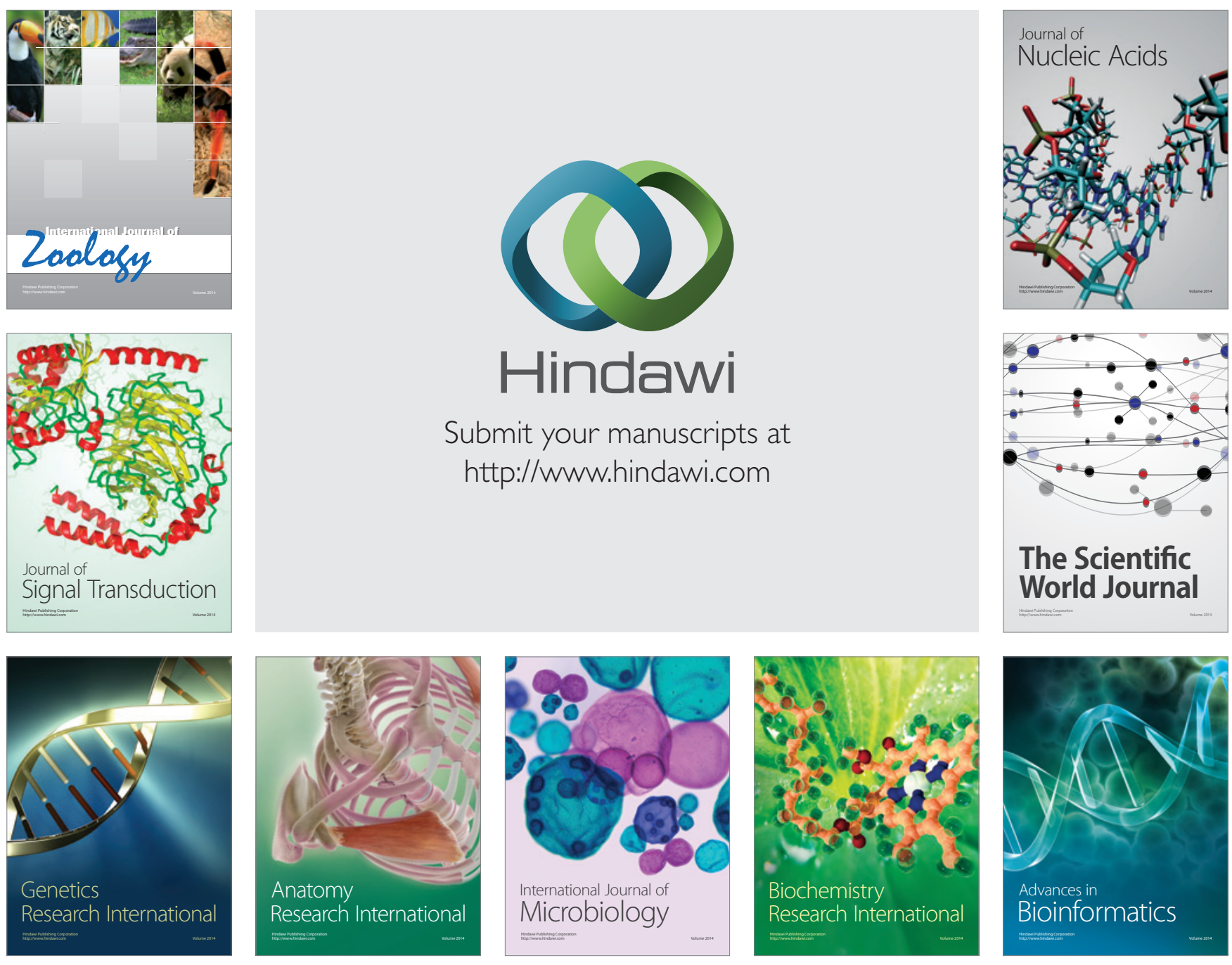

The Scientific World Journal
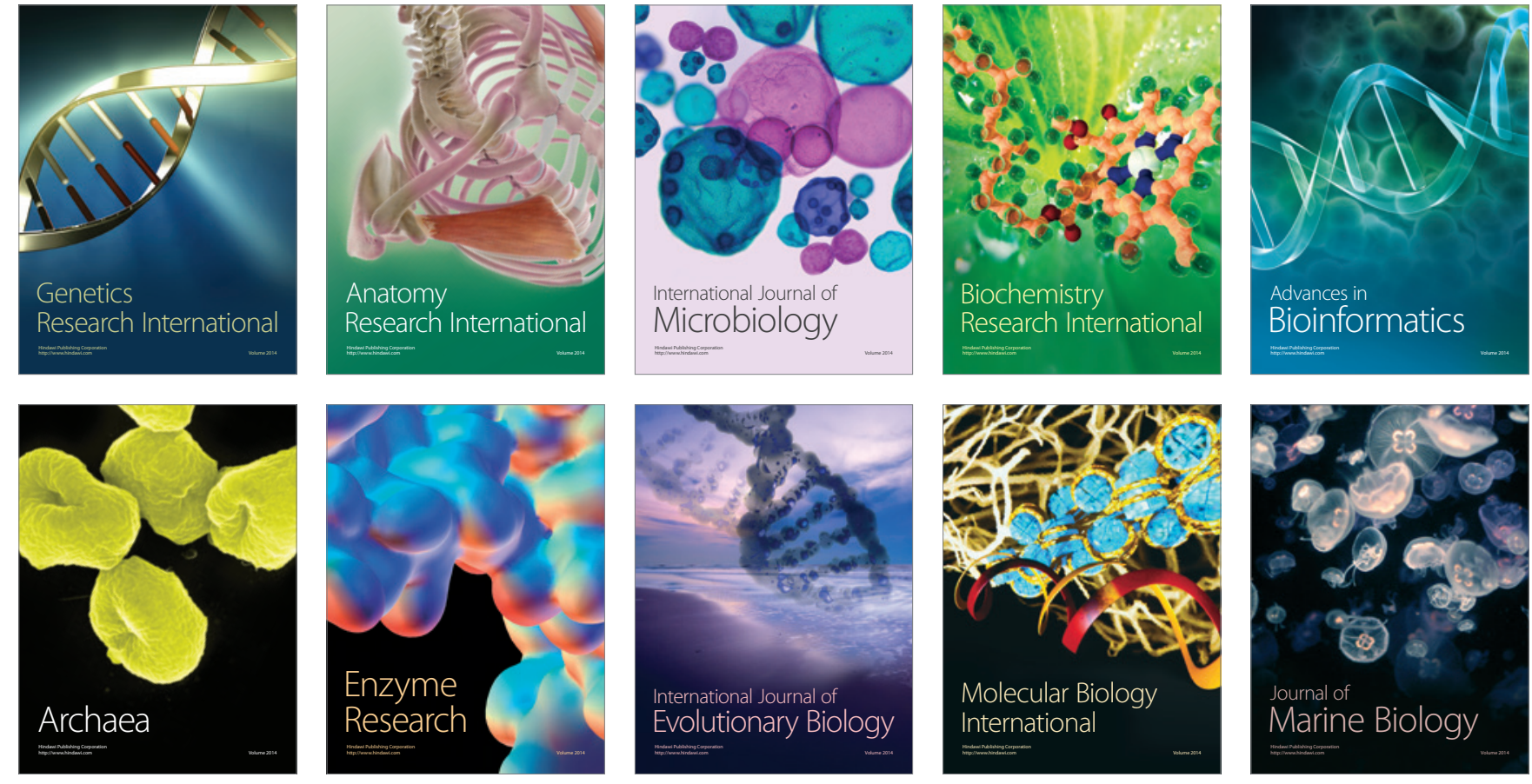